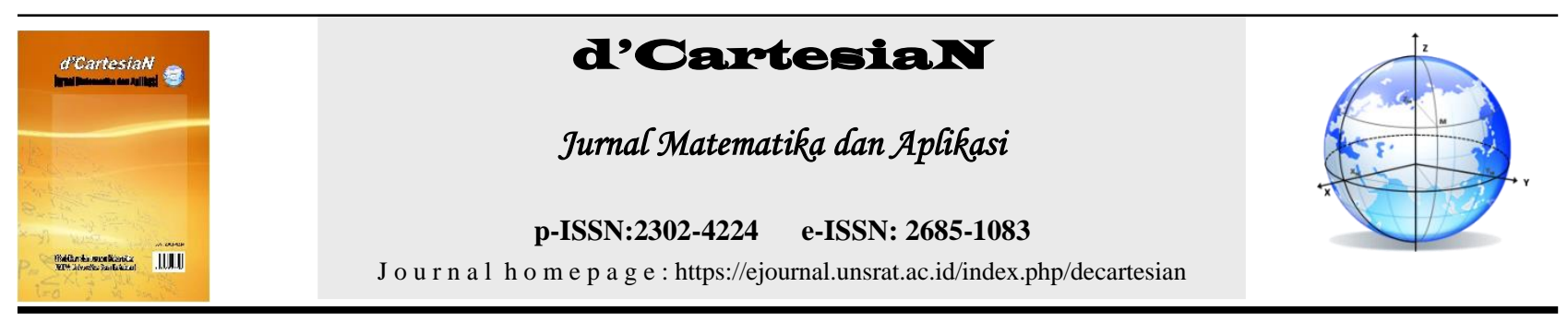

\title{
Pendekatan Generalized Linear Model Pada Regresi Kuantil Copula Normal Untuk Keterhubungan IHSG dan Kurs EUR-IDR
}

\author{
Laurentia Nindya Sari Prameswara'1, Bambang Susanto' ${ }^{1}$, Leopoldus Ricky Sasongko ${ }^{{ }^{*}}$ \\ ${ }_{1}^{1}$ Program Studi Matematika-Fakultas Sains dan Matematika-UKSW, Jln. Diponegoro No. 52-60, Salatiga 50711, Indonesia \\ *Corresponding author: leopoldus.sasongko@uksw.edu
}

\begin{abstract}
A B S T R A K
Penelitian ini bertujuan untuk memperoleh estimasi parameter dan regresi kuantil pada suatu model distribusi bivariat yang disebut Copula sebagai alternatif regresi linier klasik dalam menganalisis keterhubungan dua peubah acak. Copula adalah model distribusi bivariat yang memiliki keunggulan selain karena tidak kaku terhadap asumsi distribusi tertentu, juga dapat menyatakan keterhubungan nonlinier. Copula yang dianalisis pada penelitian ini adalah Copula Normal. Sedangkan Generalized Linear Model (GLM) adalah perluasan dari model regresi linier klasik, yang salah satu komponen utamanya adalah fungsi link. Didapati bahwa regresi kuantil pada copula Normal merupakan suatu bentuk GLM dengan fungsi invers link yaitu $G^{-1}(\Phi(\cdot))$. Regresi kuantil dan parameter copula Normal $\rho$ diestimasi dengan pendekatan GLM menggunakan metode Least Square. Estimasi regresi kuantil terbaik dilakukan dengan menghitung Mean Square Error (MSE). Validasi parameter copula dilakukan melalui simulasi dengan parametric bootstrap. Data yang digunakan dalam penelitian ini adalah data return IHSG sebagai peubah tak bebas dan data return kurs beli EUR-IDR sebagai peubah bebas. Hasil penelitian menunjukkan bahwa keterhubungan IHSG dan kurs beli EUR-IDR lemah dan tidak linier.
\end{abstract}

\section{INFO ARTIKEL :}

Diterima : 8 April 2020

Diterima setelah revisi : 29 Agustus 2020

Tersedia online : 30 Desember 2020

Ke y wo r d s :
Copula Normal,
Generalized Linear Model,
Parameter,
Ukuran Keterhubungan.

Ukuran Keterhubungan.

\begin{abstract}
A B S T R A C T
This study aims to obtain parameter estimation and quantile regression in a bivariate distribution model called Copula as an alternative to classical linear regression. The copula's advantages is not only because it's not rigid towards certain distribution assumptions, but also express nonlinear relationship. This study is focus on Normal Copula. Generalized Linear Model (GLM) is an extension of the classic linear regression model, which one of the components is the link function. It was found that the quantile regression in Normal Copula is a form of GLM. Quantile regression and Normal Copula parameter were estimated by the GLM approach using the Least Square method. The best quantile regression estimation is done by calculating the MSE. Validation of copula parameters is done through parametric bootstrap simulation. Data used in this study are the JCI return and the EUR-IDR buying rates return. The results showed that their relationship were weak and nonlinear.
\end{abstract}

\section{ARTICLE INFO}

Received : 8 April 2020

Received in revised form : 29 August 2020

Available online : 30 December 2020

\section{Keyword s:}

Copula Normal,

Generalized Linear Model,

Parameter,

Ukuran Keterhubungan.

\section{PENDAHULUAN}

Keterhubungan antardua peubah acak dapat dinyatakan melalui model distribusi bivariat, seperti model distribusi bivariat Normal atau Gaussian yang menggambarkannya secara linier. Pada kenyataannya, banyak dijumpai peubah acak yang tidak dapat memenuhi asumsi bahwa data mengikuti model distribusi bivariat Normal, seperti IHSG dan kurs rupiah terhadap valuta asing (valas). Model distribusi bivariat Normal merupakan fungsi distribusi gabungan dari dua peubah acak yang berdistribusi univariat Normal. Menurut [1], kenaikan atau penurunan IHSG dipengaruhi oleh faktor-faktor ekonomi seperti tingkat suku bunga, tingkat inflasi dan nilai tukar mata uang (valas). Mengingat bahwa IHSG dan kurs rupiah terhadap valas adalah data yang sering dijumpai tidak memenuhi asumsi distribusi univariat Normal, maka apabila akan diteliti keterhubungannya, tidak terpenuhinya asumsi model distribusi univariat Normal dapat menjadi kendala dalam penelitian.

Model distribusi bivariat tidak terbatas pada distribusi bivariat Normal saja, dan untuk memperoleh kurva regresi pada sembarang model distribusi bivariat bukan perkara yang mudah. Salah satu metode alternatifnya adalah dengan melibatkan distribusi bivariat yang disebut copula pada analisis regresi. Copula memiliki keunggulan yaitu mampu memodelkan dua peubah acak yang masing-masing distribusi marginalnya tidak termasuk dalam keluarga distribusi yang sama. 
Generalized Linear Model (GLM) adalah bentuk perluasan dari regresi linier sederhana dengan asumsi distribusi variabel respon merupakan anggota dari keluarga eksponensial. Menurut [2], tiga komponen penting yang membentuk Generalized Linear Model adalah, variabel prediktor yang linier, distribusi dari variabel respon adalah distribusi keluarga eksponensial, dan ada fungsi link (fungsi penghubung) yaitu fungsi yang menjelaskan nilai ekspektasi dari variabel respon dengan menghubungkan variabel penjelas melalui persamaan linier.

Pada penelitian [3] dan [4] didapati bahwa regresi kuantil pada model copula Normal (bivariat) merupakan suatu Generalized Linear Model (GLM). Penelitian ini mengangkat temuan tersebut untuk lebih lanjut dapat dilakukan estimasi terhadap model Copula Normal, sekaligus memperoleh regresi kuantilnya yang dapat menjelaskan keterhubungan dua peubah acak pada data bivariat. Penelitian ini membahas Indeks Harga Saham Gabungan (IHSG) dan Kurs Beli EUR (Euro) terhadap IDR (Rupiah). Keterhubungan antara Kurs Beli EURIDR dan IHSG pada penelitian ini dijelaskan melalui parameter Copula Normal yang diestimasi melalui pendekatan Generalized Linear Model (GLM) pada regresi kuantil Copula Normal. Data yang digunakan pada penelitian ini adalah data return IHSG dan return kurs beli EUR-IDR dalam waktu pengamatan 1 Januari 2018 sampai dengan 31 Desember 2018.

\subsection{Transformasi Data}

Transformasi data adalah proses mengubah skala data asli menjadi suatu skala yang berbeda sehingga data mampu memenuhi asumsi yang mendasari analisis dan data siap untuk dianalisis. Dalam bidang analisis keuangan, salah satu bentuk transformasi yang sering dilakukan adalah transformasi return [5]. Return merupakan hasil yang diperoleh dari investasi yaitu perubahan nilai investasi pada waktu $t$ dengan $t-1$. Return dapat berupa penghasilan (gain) atau kerugian (loss) [6].

Persamaan transformasi return yang digunakan pada penelitian ini yaitu [5]

$$
\begin{aligned}
& x_{t}=-\ln \frac{\operatorname{Kurs}_{t}}{\operatorname{KurS}_{t-1}} \\
& y_{t}=\ln \frac{I H S G_{t}}{I H S G_{t-1}}
\end{aligned}
$$

dengan Kurs $_{t}$ adalah nilai Kurs Beli EUR-IDR pada waktu $t, I H S G_{t}$ adalah nilai IHSG pada waktu $t$, sehingga diperoleh data bivariat $\left(x_{t}, y_{t}\right)$.

\subsection{Model Distribusi Univariat}

Pada penelitian ini akan dibahas model distribusi univariat untuk peubah acak kontinu, yaitu model distribusi Normal dan Laplace.

Jika dimiliki peubah acak kontinu $X$ maka notasi model distribusi univariat Normalnya adalah
$X \sim \mathcal{N}\left(\mu, \sigma^{2}\right)$. Fungsi distribusi univariat Normal untuk peubah acak $X$ didefinisikan sebagai berikut

$$
F_{x}(x)=\frac{1}{\sigma \sqrt{2 \pi}} \int_{-\infty}^{x} \exp \left\{-\frac{1}{2}\left(\frac{t-\mu}{\sigma}\right)^{2}\right\} d t, x \in(0, \infty)
$$

dengan $\mu \in \mathbb{R}$, dan $\sigma^{2}>0$.

Misal terdapat peubah acak $X$ berdistribusi Laplace dengan parameter lokasi $\mu \in \mathbb{R}$ dan parameter skala $b \in$ $(0, \infty)$ atau dinotasikan $X \sim \operatorname{Laplace}(\mu, b)$, maka fungsi distribusi Laplace didefinisikan sebagai berikut

$$
F_{x}(x)= \begin{cases}\frac{1}{2} \exp \left(\frac{x-\mu}{b}\right), & x \in(-\infty, b] \\ 1-\frac{1}{2} \exp \left(-\frac{x-\mu}{b}\right), & x \in[b, \infty)\end{cases}
$$

Dengan $\quad \mu=\operatorname{mean}(x)=\operatorname{median}(x) . \quad$ Distribusi Laplace merupakan anggota distribusi location-scale family, yang memiliki hubungan dengan distribusi keluarga eksponensial. Jika dimiliki peubah acak $X \sim \operatorname{Laplace}(\mu, b)$, maka $|X-\mu| \sim$ Eksponensial $\left(\frac{1}{b}\right)$ [7].

\subsection{Uji Kecocokan Distribusi}

Uji kecocokan distribusi digunakan untuk mengukur tingkat kecocokan distribusi marginal data terhadap suatu distribusi tertentu. Uji ini penting dilakukan karena digunakan sebagai penduga parameter return IHSG dan return Kurs Beli EUR-IDR. Pada penelitian ini digunakan uji distribusi dari keluarga empirical distribution function goodness of fit test, yaitu uji Kolmogorov-Smirnov, Anderson-Darling, dan Cramér von Misses [8]. Ketiga uji tersebut dapat dilakukan dengan menentukan hipotesis sebagai berikut

$H_{0}$ : data mengikuti distribusi parametrik $F^{*}(x)$

$H_{1}$ : data tidak mengikuti distribusi parametrik $F^{*}(x)$

\subsubsection{Uji Kolmogorov-Smirnov}

Uji Kolmogorov-Smirnov dilakukan dengan menghitung statistik uji $D$ sebagai berikut [9]

$$
D=\max _{x_{(1)} \leq x \leq x_{(n)}}\left|\hat{F}(x)-F^{*}(x)\right|
$$

Nilai D menyatakan perbedaan terbesar antara fungsi distribusi empirik $\hat{F}(x)$ dengan distribusi teoritis $\hat{F}(x)$ diujikan, sehingga dapat ditulis

$$
D=\max _{i \in\{1, . ., n\}}\left\{\max \left\{\left|\frac{i-1}{n}-F^{*}\left(x_{(i)}\right)\right|,\left|\frac{i}{n}-F^{*}\left(x_{(i)}\right)\right|\right\}\right\}
$$

Dimana $x_{i}, i=1,2, \ldots, n$ adalah data ke- $i$ setelah diurutkan.

Penarikan kesimpulan uji ini didasarkan pada nilai statistik $D$, yaitu jika nilai $D$ melebihi batas kritis $D_{\alpha}$. Nilai $D_{\alpha}$ untuk $\alpha=0.10,0.05,0.01$ secara berurutan adalah $\frac{1.224}{\sqrt{n}}, \frac{1.358}{\sqrt{n}}, \frac{1.628}{\sqrt{n}}$. Apabila $D>D_{\alpha}$, maka $H_{0}$ ditolak atau jika $P_{\text {value }}<\alpha$ maka $H_{0}$ ditolak.

\subsubsection{Uji Anderson-Darling}

Statistik uji Anderson-Darling didefinisikan sebagai berikut [9]

$$
\begin{array}{r}
A^{2}=-\frac{1}{n}\left[\sum_{j=i}^{n}(2 j-1)\left\{\log \left[F^{*}\left(x_{(j)}\right)\right]+\log \left[1-F^{*}\left(x_{(n+1-j)}\right)\right]\right\}\right]-n(6) \\
\text { Pengambilan keputusan uji Anderson-Darling }
\end{array}
$$
didasarkan pada perbandingan statistik uji $A^{2}$ dengan 


\section{Pendekatan Generalized Linear Model Pada Regresi Kuantil Copula Normal Untuk Keterhubungan IHSG dan Kurs EUR-IDR \\ d'Cartesian: Jurnal Matematika dan Aplikasi, Vol. 9, No. 2 (September 2020): 97-104}

nilai kritis. Pada signifikansi $\alpha=0.10,0.05$, dan 0.01 , nilai kritisnya secara berurutan adalah $1.933,2.492$, dan 3.857. Apabila $A^{2}>$ nilai kritis, maka $H_{0}$ ditolak atau jika $P_{\text {value }}<\alpha$ maka $H_{0}$ ditolak.

\subsubsection{Uji Cramér von Misses}

Uji Cramér von Misses dilakukan dengan menghitung statistik uji sebagai berikut [10]

$$
W^{2}=\frac{1}{12 n}+\sum\left(p_{(i)}-\frac{2 i-1}{2 n}\right)^{2}
$$

Pengambilan kesimpulan uji ini didasarkan pada perbandingan nilai statistik $W^{2}$ dengan nilai kritis $c_{1-\alpha}$, yakni jika $W^{2}>c_{1-\alpha}$ maka $H_{0}$ ditolak. Tabel nilai kritis dapat dilihat di [11].

\subsection{Ukuran Keterhubungan}

Terdapat dua jenis ukuran keterhubungan yang umum digunakan yaitu koefisien korelasi Pearson dan Spearman's Rho.

Koefisien korelasi Pearson untuk $n$ sampel peubah acak $(X, Y)$ yaitu $\left(x_{1}, y_{1}\right), \ldots,\left(x_{n}, y_{n}\right)$ dihitung oleh

$$
r=\frac{\sum_{i=1}^{n}\left(x_{i}-\bar{x}\right)\left(y_{i}-\bar{y}\right)}{\sqrt{\sum_{i=1}^{n}\left(x_{i}-\bar{x}\right)^{2}} \sqrt{\sum_{i=1}^{n}\left(y_{i}-\bar{y}\right)^{2}}}
$$

Koefisien korelasi Spearman's Rho dapat dihitung dengan persamaan berikut

$$
\rho=1-\frac{6 \sum d_{i}^{2}}{n\left(n^{2}-1\right)}
$$

dengan $d_{i}$ merupakan selisih dua peringkat dari setiap data pengamatan. Misal diketahui data pengamatan $\left(X_{1}, Y_{1}\right),\left(X_{2}, Y_{2}\right), \ldots,\left(X_{n}, Y_{n}\right) \quad$ maka $\quad d_{i}=\operatorname{rank}\left(x_{i}\right)-$ $\operatorname{rank}\left(y_{i}\right)$, untuk $i=1, \ldots, n$.

\subsection{Copula}

Berdasarkan Teorema Sklar, jika terdapat fungsi distribusi bivariat $H$ dengan fungsi distribusi marginalmarginalnya, $F(x)$ dan $G(y)$ kontinu, maka terdapat suatu copula $H$ untuk semua $x$ dan $y$ sedemikian sehingga berlaku [12]

$$
H(x, y)=C(F(x), G(y))
$$

Fungsi Kepadatan Copula dinyatakan oleh

$$
h(x, y)=c(F(x), G(y)) f(x) g(y)
$$

dengan $c(u, v)=\frac{\partial^{2} c(u, v)}{\partial u \partial v}, f(x)$ dan $g(x)$ secara berurutan adalah fungsi kepadatan probabilitas dari peubah acak $X$ dan $Y$. Berdasarkan [13] terdapat tiga properti bersyarat copula, yaitu fungsi kepadatan probabilitas bersyarat, fungsi distribusi bersyarat, dan fungsi distribusi bivariat dalam kaitannya dengan copula.

Hubungan fungsi kepadatan probabilitas $Y=y$ bersyarat $X=x$, yaitu $k(y \mid x)$ dengan copula dinyatakan sebagai berikut

$$
k(y \mid x)=\frac{h(x, y)}{f(x)}=c(F(x), G(y)) g(y)
$$

Hubungan fungsi distribusi $Y$ bersyarat $X=x$ yaitu $K(y \mid x)$ dengan copula yaitu

$$
K(y \mid x)=\operatorname{Pr}[Y \leq y \mid X=x]
$$

$$
\begin{aligned}
& =\int_{0}^{y} k(s \mid x) d s=\int_{0}^{y} c(F(x), G(s)) g(s) d s \\
K(y \mid x) & =\int_{0}^{G(y)} \frac{\partial^{2} C(F(x), q)}{\partial F(x) \partial q} d q \\
& =\frac{\partial C(F(x), G(y))}{\partial F(x)}
\end{aligned}
$$

Sedangkan hubungan ekspektasi peubah acak $Y$ bersyarat $X=x$ dengan copula dinyatakan sebagai berikut

$$
\begin{aligned}
E[Y \mid X=x] & =\int_{-\infty}^{\infty} y k(y \mid x) d y \\
& =\int_{-\infty}^{\infty} y c(F(x), G(y)) g(y) d
\end{aligned}
$$

\subsection{Regresi Kuantil $\alpha$}

Kebergantungan peubah acak satu terhadap yang lain dapat dijelaskan melalui analisis regresi, dan salah satu regresi yang dapat digunakan adalah regresi kuantil. Menurut [13] kurva kuantil $\alpha$ dari $Y$ pada $X$ adalah $\hat{y}=\hat{y}_{\alpha}(x)$ yang merupakan solusi dari persamaan $K(y \mid x)=\operatorname{Pr}[Y \leq y \mid X=x]=\alpha, \quad$ untuk $\quad 0<\alpha<1$. Sedangkan pada suatu copula, kurva kuantil $\alpha$ dari $V$ pada $U$ adalah $\hat{v}=\hat{v}_{\alpha}(u)$ yang merupakan solusi dari $\frac{\partial C(u, v)}{\partial u}=\operatorname{Pr}[V \leq v \mid U=u]=\alpha$, untuk $0<\alpha<1$.

Persamaan (13) jika disetarakan dengan $\alpha$ dapat ditulis sebagai berikut

$$
K(y \mid x)=\frac{\partial C(F(x), G(y))}{\partial F(x)}=\alpha
$$

Maka solusi dari persamaan di atas adalah $\hat{v}=G(\hat{y})$ dan dapat diperoleh kurva regresi kuantil yaitu $\hat{y}=G^{-1}(\hat{v})$.

\subsection{Copula Normal}

Bentuk umum Copula Normal didefinisikan sebagai berikut

$$
C_{G a}(u, v)=\Phi_{\rho}\left(\Phi^{-1} u, \Phi^{-1}(v)\right)
$$

dimana $\Phi_{\rho}$ adalah fungsi distribusi bivariat Normal dengan korelasi Pearson $\rho$, dan $\Phi$ adalah fungsi distribusi normal. Properti bersyarat Copula Normal ditunjukkan oleh persamaan berikut

$$
\frac{\partial C_{G, \rho}(u, v)}{\partial u}=\Phi\left(\frac{\Phi^{-1}(v)-\rho \Phi^{-1}(u)}{\sqrt{1-\rho^{2}}}\right)
$$

Selanjutnya, berdasarkan [14] persamaan Spearman's rho untuk Copula Normal dinyatakan sebagai berikut

$$
\rho_{S}=\frac{6}{\pi} \arcsin \left(\frac{\rho}{2}\right)
$$

dengan $\rho$ adalah koefisien korelasi Pearson.

Kurva kuantil bersyarat atau regresi kuantil $\alpha$ copula Normal adalah kurva $\hat{v}_{\alpha}(u)$ yang merupakan solusi dari (16) yang disetarakan dengan $\alpha$ sehingga diperoleh [15]

$$
\hat{v}_{\alpha}(u)=\Phi\left(\Phi^{-1}(\alpha) \sqrt{1-\rho^{2}}+\rho \Phi^{-1}(u)\right)
$$

Mengingat $u=F(x)$ dan $v=G(y)$, maka $y=G^{-1}(v)$. Regresi kuantil $\alpha$ dalam bentuk $\hat{y}_{\alpha}(x)$ diberikan oleh $\hat{y}_{\alpha}(x)=G^{-1}\left(\hat{v}_{\alpha}(F(x))\right)$ 


$$
=G^{-1}\left(\Phi\left(\Phi^{-1}(\alpha) \sqrt{1-\rho^{2}}+\rho \Phi^{-1}(F(x))\right)\right)
$$

\subsection{Uji Kecocokan Copula}

Guna melihat seberapa cocok copula dalam mencerminkan perilaku data, perlu dilakukan uji kecocokan copula. Uji ini dapat dilakukan setelah memperoleh parameter copula. Pada uji kecocokan copula, digunakan ukuran statistik Cramér von Misses $S_{n}$ yang diperoleh dari [13]

$$
S_{n}=\sum_{i=1}^{n}\left[H_{e}\left(x_{i}, y_{i}\right)-H_{\widehat{\theta}}\left(x_{i}, y_{i}\right)\right]^{2}
$$

dengan $H_{e}\left(x_{i}, y_{i}\right)=C_{e}\left(F\left(x_{i}\right), G\left(y_{i}\right)\right)=\frac{\#\left(x \leq x_{i}, y \leq y_{i}\right)}{n+1}$ adalah fungsi distribusi bivariat empirik untuk data untuk data, $\left\{\left(x_{i}, y_{i}\right)\right\}, i=1,2, \ldots, n, \quad$ sedangkan $\quad \#\left(x \leq x_{i}, y \leq y_{i}\right)$ menyatakan banyaknya data bivariat $\left\{\left(x_{i}, y_{i}\right)\right\}$ dengan $x \leq x_{i}$ dan $y \leq y_{i}$.

Ukuran statistik Cramér von Misses, nilai $S_{n}$ menyatakan kecocokan data terhadap suatu copula. Ukuran kecocokan ini bergantung pada nilai $S_{n}$ terkecil. Selain melalui $S_{n}$, besaran $P_{\text {value }}$ juga menentukan kecocokan copula dalam mencerminkan perilaku data, yang mana nilai $P_{\text {value }}$ dapat diperoleh dari parametric bootstrap [16].

\subsection{Simulasi Pembangkitan Bilangan Acak Bivariat Menggunakan Copula}

Pembangkitan bilangan acak bivariat $\{(x, y)\}$ dari suatu fungsi distribusi bivariat $H$ harus dibangkitkan secara bersama-sama. Salah satu caranya adalah menggunakan Copula berdasarkan persamaan (13). Misalkan fungsi $\frac{\partial C(u, v)}{\partial u}$ merupakan fungsi dalam $v$, dengan $u=F(x)$ dan $v=G(y)$,

$$
Z_{u}=\frac{\partial C(u, v)}{\partial u}
$$

Langkah-langkah pembangkitan bilangan acak $\{(x, y)\}$ sebagai berikut:

1. Bangkitkan dua bilangan acak saling bebas $u$ dan $t$, berdistribusi seragam di $[0,1]$;

2. Dapatkan $v=Z_{u}{ }^{(-1)}(t)$, dimana $Z_{u}{ }^{(-1)}$ adalah invers fungsi $Z_{u}$;

3. Dapatkan sepasang bilangan acak bivariat dari suatu copula yaitu $(u, v)$;

4. Dapatkan sepasang bilangan acak bivariat $(x, y)=$ $\left(F^{-1}(u), G^{-1}(v)\right)$;

\subsection{Parametric Bootstrap untuk Ukuran Statistik Cramér von Misses}

Ukuran statistik $\left(S_{n}\right)$ dan $P_{\text {value }}$ Cramér von Misses $\left(S_{n}\right)$ dapat diperoleh melalui simulasi parametric bootstrap yang algoritmanya dijabarkan sebagai berikut:

Diketahui data bivariat sebanyak $n$ pasang yaitu $\left\{\left(x_{a}, y_{a}\right)\right\}, a=0,1,2,3, \ldots, n$. Untuk $N$ bilangan bulat positif sangat besar,
1. Bangkitkan $n$ sampel acak bivariat $\left\{\left(x_{i}, y_{i}\right)\right\}$ dengan $i=0,1,2, \ldots, n$ dari suatu distribusi bivariat $H_{\theta}(x, y)$ atau Copula $C_{\theta}(F(x), G(y))$,

2. Hitung $H_{e}\left(x_{i}, y_{i}\right)=C_{e}\left(F\left(x_{i}\right), G\left(y_{i}\right)\right)=\frac{\#\left(x_{a} \leq x_{i}, y_{a} \leq y_{i}\right)}{n+1}$ dengan \# $\left(x_{a} \leq x_{i}, y_{a} \leq y_{i}\right)$ adalah banyak data bivariat $\left\{\left(x_{a}, y_{a}\right)\right\}$ dengan $x_{a} \leq x_{i}$ dan $y_{a} \leq y_{i}$,

3. Untuk $j=1$, hitung

$$
\begin{aligned}
s_{n, j}^{*} & =\sum_{i=1}^{n}\left[H_{e}\left(x_{i}, y_{i}\right)-H_{\theta}\left(x_{i}, y_{i}\right)\right]^{2} \\
& =\sum_{i=1}^{n}\left[C_{e}\left(F\left(x_{i}\right), G\left(y_{i}\right)\right)-C_{\theta}\left(F\left(x_{i}\right), G\left(y_{i}\right)\right)\right]^{2}
\end{aligned}
$$

4. Untuk $j=j+1$, ulangi poin 1 sampai poin 3 , ke poin 5 jika $j=N+1$,

5. Hitung $P_{\text {value }}, \frac{\#\left(s_{n, j}^{*}>s_{n}\right)}{N}$ atau $\sum_{j=1}^{N}\left(\frac{I\left(s_{n, j}^{*}>s_{n}\right)}{N}\right)$, yang mana $I\left(s_{n, j}^{*}>s_{n}\right)$ adalah fungsi bernilai 1 untuk nilai $s_{n, j}^{*}>s_{n}$.

\subsection{Generalized Linear Model}

Generalized Linear Model (GLM) merupakan suatu bentuk perluasan dari regresi linier klasik dengan asumsi variabel responnya diperbolehkan tidak berdistribusi Normal univariat, tetapi distribusinya harus merupakan anggota dari distribusi keluarga eksponensial. Berdasarkan [17], terdapat tiga komponen utama dalam GLM yaitu

1. Random component: merupakan variabel respon $y_{1}, y_{2}, \ldots, y_{n}$ yang berasal dari distribusi keluarga eksponensial dan saling bebas.

2. Linear predictor atau Systematic component: merupakan kombinasi linier dari parameter $\boldsymbol{\beta}=$ $\left(\beta_{1}, \beta_{2}, \ldots, \beta_{p}\right)^{T}$ dan matriks variabel $\boldsymbol{X}$ berukuran $n \times p$ yang berisikan $p$ variabel penjelas untuk $n$ pengamatan, yang dinyatakan dalam persamaan $\boldsymbol{\eta}=\boldsymbol{X} \boldsymbol{\beta}$.

3. Link function: merupakan fungsi yang menghubungkan linier prediktor dengan nilai ekspektasi variabel respon $Y$ melalui persamaan $g[E(y)]=\boldsymbol{X} \boldsymbol{\beta}$.

\section{Generalized Linear Model (GLM) pada Regresi Kuantil Copula Normal}

Pada penelitiannya, [4] menyebutkan bahwa pendekatan GLM untuk mengestimasi parameter suatu copula menghasilkan bentuk yang eksplisit. Pada persamaan regresi kuantil $\alpha$ pada (20), didapati bahwa $\hat{y}_{\alpha}(x)$ merupakan suatu Generalized Linear Model (GLM) yang dapat dituliskan ulang sebagai

$$
\hat{y}_{\alpha}(x)=G^{-1}(\Phi(a+b z))
$$

dengan $a=\Phi^{-1}(\alpha) \sqrt{1-\rho^{2}}, b=\rho$, dan $z=\Phi^{-1}(F(x))$. Artinya bahwa kurva $\hat{y}_{\alpha}(x)$ adalah GLM terhadap $z=$ $\Phi^{-1}(F(x))$ dengan fungsi invers link $G^{-1}(\Phi(\cdot))$ atau fungsi komposisi $G^{-1} \circ \Phi$. Pada (19), kurva $\hat{v}_{\alpha}(u)$ juga merupakan suatu GLM terhadap $u=F(x)$ dengan fungsi invers link $\Phi$. Dengan begitu, transformasi peubah acak $X$ terhadap $F$ menjadi $U$ dan $Y$ terhadap $G$ menjadi $V$ 


\section{Pendekatan Generalized Linear Model Pada Regresi Kuantil Copula Normal Untuk Keterhubungan IHSG dan Kurs EUR-IDR \\ d'Cartesian: Jurnal Matematika dan Aplikasi, Vol. 9, No. 2 (September 2020): 97-104}

adalah krusial guna pendekatan GLM dapat dilakukan. Estimasi GLM dapat dilakukan dengan bantuan metode Least Square sehingga dapat diperoleh parameter $\rho=b$ (parameter copula Normal) dan $\alpha=\Phi\left(a / \sqrt{1-b^{2}}\right)$ atau parameter penentu regresi kuantil.

\subsection{Pemilihan Regresi Kuantil Terbaik}

Pada penelitian ini, pemilihan model regresi terbaik dilakukan dengan menghitung nilai Mean Square Error (MSE). Mean Square Error (MSE) adalah rata-rata dari jumlahan error yang dikuadratkan dan dinyatakan sebagai berikut

$$
\operatorname{MSE}(\hat{y})=\frac{1}{n} \sum_{i=1}^{n}\left(\hat{y}_{t}-y_{t}\right)^{2}
$$

dengan $\hat{y}_{t}$ adalah nilai ekspektasi dari regresi kuantil, $y_{t}$ adalah data aktual pada waktu $t$ dan $n$ adalah banyaknya data.

\section{Metode Penelitian}

Langkah awal penelitian ini adalah melakukan pengolahan data IHSG dan Kurs Beli EUR-IDR. Data diolah dengan melakukan transformasi data menggunakan teknik transformasi return seperti pada persamaan (1) dan (2) sehingga diperoleh data bivariat $\left(x_{t}, y_{t}\right)$.

Langkah selanjutnya adalah menganalisis data marginal $x_{t}$ dan $y_{t}$ dengan langkah-langkah berikut:

1. Menggambarkan dan melakukan analisis statistika deskriptif pada data marginal $x_{t}$ dan $y_{t}$ untuk melihat karakteristik data.

2. Menghitung korelasi data yang dipasangkan secara bivariat, yaitu $\left(x_{t}, y_{t}\right)$.

3. Melakukan uji kecocokan distribusi Normal dan Laplace pada data marginal $x_{t}$ dan $y_{t}$ menggunakan uji Kolmogorov-Smirnov, Anderson-Darling, Cramér von Misses.

Kemudian dilakukan analisis lanjutan dengan langkah-langkah berikut:

1. Estimasi parameter copula Normal $\rho$ dari keterhubungan data bivariat $\left(x_{t}, y_{t}\right)$ dengan kombinasi marginal-marginal

$$
\begin{aligned}
& x_{t}=\text { Normal, Laplace }, \text { dan } \\
& y_{t}=\text { Normal, Laplace }
\end{aligned}
$$

melalui Generalized Linear Model (GLM) diakukan dengan Least Square Method (LSM) yaitu dengan mencari solusi persamaan (20).

2. Menentukan regresi kuantil terbaik dengan mencari nilai Mean Square Error (MSE) terkecil sesuai persamaan (24).

3. Menguji kecocokan model distribusi bivariat atau copula Normal pada data bivariat $\left(x_{t}, y_{t}\right)$ berdasarkan statistik uji Cramér von Misses dengan simulasi parametric boostrap.

4. Melakukan validasi parameter copula Normal $\rho$ menggunakan metode simulasi, yaitu dengan langkah sebagai berikut: i. Bangkitkan sepasang bilangan acak bivariat dari copula Normal, yaitu $(u, v)$ sebanyak $k$, dimana $k$ adalah ukuran data hasil transformasi;

ii. Peroleh sepasang bilangan acak bivariat $(x, y)=\left(F^{-1}(u), G^{-1}(v)\right) ;$

iii.Hitung fungsi distribusi empirik dari masingmasing $x$ dan $y$, yaitu $F_{e}(x)$ dan $G_{e}(y)$;

iv.Hitung parameter $\rho$ melalui korelasi Spearman's rho berdasarkan $F_{e}(x)$ dan $G_{e}(y)$;

v. Ulangi langkah 1-4 sebanyak 100 kali dengan simulasi parametric bootstrap untuk memperoleh nilai $P_{\text {value }}$;

vi. Bandingkan $P_{\text {value }}$ untuk parameter copula Normal $\rho$ hasil simulasi dengan $P_{\text {value }}$ untuk parameter copula Normal $\rho$ dari estimasi dengan pendekatan Generalized Linear Model.

\section{HASIL DAN PEMBAHASAN}

\section{1. Analisis Data Marginal}

Data penelitian ini, yaitu kurs beli EUR-IDR dan IHSG dilakukan transformasi return menggunakan persamaan (1) dan (2) sehingga diperoleh data bivariat $\left(x_{t}, y_{t}\right)$ yang digambarkan sebagai berikut

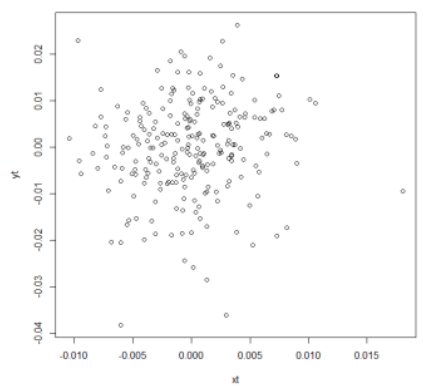

(a)
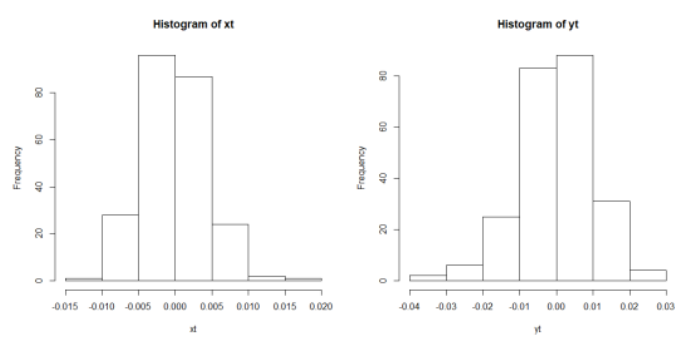

(b)

Gambar 1. Scatterplot $\left(\boldsymbol{x}_{\boldsymbol{t}}, \boldsymbol{y}_{\boldsymbol{t}}\right)$ (a), histogram $\boldsymbol{x}_{\boldsymbol{t}}$ (b kiri), dan histogram $y_{t}$ (b kanan)

Pada Gambar 1.a dan Gambar 1.b terdapat histogram untuk masing-masing data marginal $x_{t}$ dan $y_{t}$. Selanjutnya untuk menganalisis perilaku data, dilakukan analisis statistik deskriptif yang disajikan pada tabel berikut.

Tabel 1. Statistik Deskriptif Data Marginal $x_{t}$ dan $y_{t}$

\begin{tabular}{ccccccc}
\hline & Min & $Q_{1}$ & Median & Mean & $Q_{1}$ & Max \\
\hline$x_{t}$ & -0.01046 & 0.00305 & -0.00018 & -0.0000983 & 0.00269 & 0.01803 \\
\hline$y_{t}$ & -0.03828 & -0.00562 & 0.00056 & -0.0000966 & 0.00648 & 0.02633 \\
\hline
\end{tabular}


Berdasarkan Gambar 1.a dan Gambar 1.b dapat dilihat dari histogram data marginal berbentuk menyerupai lonceng dan kemudian berdasarkan Tabel 1 diketahui bahwa rata-rata data marginal berada di sekitar nol, dengan nilai minimum dan maksimum yang juga berada di sekitar nol. Selanjutnya, ukuran keterhubungan Spearman's rho dan Pearson untuk mengetahui besar dan arah hubungan peubah $x_{t}$ dan $y_{t}$ dinyatakan dalam tabel berikut

Tabel 2. Ukuran Keterhubungan Spearman's rho dan Pearson dari Peubah $x_{t}$ dan $y_{t}$

\begin{tabular}{ccc}
\hline \multirow{2}{*}{ Data bivariat } & \multicolumn{2}{c}{ Ukuran Keterhubungan } \\
\cline { 2 - 3 } & Spearman $\left(\hat{\rho}_{s}\right)$ & Pearson $(\hat{\rho})$ \\
\hline$\left(x_{t}, y_{t}\right)$ & 0.1522472 & 0.1111702 \\
\hline
\end{tabular}

\section{2. Uji Kecocokan Distribusi Marginal $x_{t}$ dan $y_{t}$}

Uji kecocokan distribusi Normal dan Laplace dilakukan terhadap data marginal $x_{t}$ dan $y_{t}$. Pemilihan dua distribusi tersebut dikarenakan keduanya merupakan anggota distribusi keluarga eksponensial yang merupakan syarat pendekatan Generalized Linear Model (GLM). Selain itu, distribusi Normal dan Laplace merupakan distribusi untuk peubah acak kontinu di $[-\infty, \infty]$. Berikut hasil uji kecocokan distribusi Normal dan Laplace serta estimasi parameter distribusi marginalnya.

Tabel 3. Hasil Uji Kecocokan Distribusi Marginal Data dan Estimasi Parameter Distribusi

\begin{tabular}{ccc}
\hline \multicolumn{1}{c}{ Dist. } & Normal & Laplace \\
\hline Marg. & \multicolumn{2}{c}{$x_{t}$} \\
Parameter & $\mu_{x_{t}}=-0.00001$ & $\mu_{x_{t}}=-0.00018$ \\
& $\sigma_{x_{t}}=0.00429$ & $b_{x_{t}}=0.00332$ \\
KS test & 0.8021 & 0.591 \\
p-value AD test & 0.9441 & 0.4481 \\
CVM test & 0.8694 & 0.5104 \\
\hline Dist. & Normal & Laplace \\
\hline Marg. & \multicolumn{2}{c}{$y_{t}$} \\
Parameter & $\mu_{y_{t}}=-0.00001$ & $\mu_{y_{t}}=-0.00018$ \\
KS test & $\sigma_{y_{t}}=0.00429$ & $b_{y_{t}}=0.00332$ \\
p-value AD test & 0.446 & 0.7571 \\
CVM test & 0.358 & 0.4555 \\
\hline
\end{tabular}

Berdasarkan tabel di atas, $H_{0}$ dari ketiga uji distribusi diterima pada tingkat signifikansi $\alpha=5 \%$. Hal ini dikarenakan $P_{\text {value }}$ semua uji lebih dari 0.05 . Oleh karena itu, setiap data marginal $x_{t}$ dan $y_{t}$ memiliki dua pilihan distribusi yang dapat digunakan untuk menentukan regresi kuantil, yaitu marginal $x_{t}$ : Normal, Laplace dan $y_{t}$ : Normal, Laplace.

\section{3. Estimasi Parameter Copula Normal}

Parameter Copula Normal $\rho$ diestimasi untuk kombinasi marginal marginal $x_{t}$ : Normal, Laplace dan $y_{t}$ : Normal, Laplace dengan metode Generalized Linear Model-Least Square. Estimasi parameter Copula Normal $\rho$ disajikan pada Tabel 4 .
Tabel 4. Hasil Estimasi Parameter Copula Normal $\rho$

\begin{tabular}{cll}
\hline Model & \multicolumn{1}{c}{$\rho$} & Regresi Kuantil $\alpha$ \\
\hline Model 1 & 0.1111702 & $\alpha=0.5$ \\
Model 2 & 0.1208913 & $\alpha=0.4824174$ \\
Model 3 & 0.12437 & $\alpha=0.4993879$ \\
Model 4 & 0.1345346 & $\alpha=0.4817239$ \\
\hline
\end{tabular}

dengan Model 1: $x_{t} \sim$ Normal dan $y_{t} \sim$ Normal, Model 2: $x_{t} \sim$ Normal dan $y_{t} \sim$ Laplace, Model 3: $x_{t} \sim$ Laplace dan $y_{t} \sim$ Normal, dan Model 4: $x_{t} \sim$ Laplace dan $y_{t} \sim$ Laplace.

\section{4. Uji Kecocokan Copula Normal}

Guna melihat seberapa cocok copula Normal dalam mencerminkan perilaku data bivariat $\left(x_{t}, y_{t}\right)$ dari keempat model, dilakukan uji kecocokan copula. Uji ini dilakukan dengan menghitung statistik Cramér von Misses $\left(S_{n}\right)$, kemudian dilakukan pembangkitan $S_{n}$ sebanyak 1000 melalui parametric bootstrap. Setelah diperoleh 1000 nilai $S_{n}$, simulasi diulang sebanyak 100 kali untuk memperoleh nilai $P_{\text {value }}$. Berdasarkan perhitungan tersebut dipilih $P_{\text {value }}$ tertinggi untuk menunjukkan model terbaik. Berikut perolehan nilai $S_{n}$ dan $P_{\text {value }}$.

Tabel 5. Hasil Uji Kecocokan Distribusi Marginal Data dan Estimasi Parameter Distribusi

\begin{tabular}{|c|c|c|c|}
\hline \multicolumn{2}{|c|}{ Distribusi } & \multirow{2}{*}{$P_{\text {value }}$} & \multirow{2}{*}{$S_{n}$} \\
\hline$X$ & Y & & \\
\hline Normal & Normal & 0.953 & 0.06092145 \\
\hline Normal & Laplace & 0.102 & 0.07808087 \\
\hline Laplace & Normal & 0.968 & 0.08598796 \\
\hline Laplace & Laplace & 0.269 & 0.0861804 \\
\hline
\end{tabular}

Tabel di atas menunjukkan bahwa $P_{\text {value }}$ tertinggi dimiliki oleh kombinasi marginal $x_{t} \sim$ Laplace dan $y_{t} \sim$ Normal dengan nilai 0.968. Histogram simulasi $S_{n}$ untuk Model 3 dengan $x_{t} \sim$ Laplace dan $y_{t} \sim$ Normal disajikan pada Gambar 2.

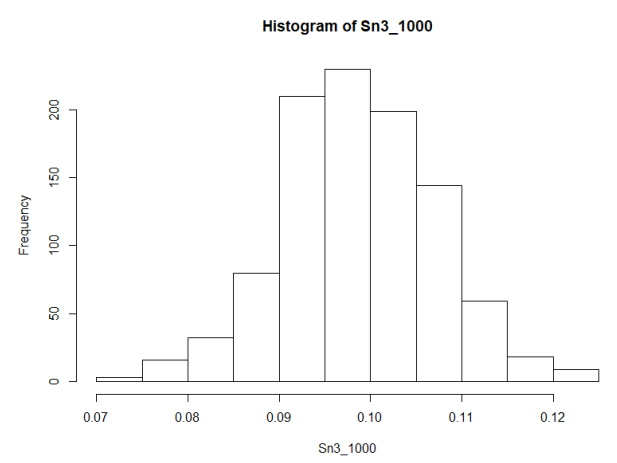

Gambar 2. Histogram $\boldsymbol{S}_{\boldsymbol{n}}$ (1000 nilai) Copula Normal untuk Model 3

Berdasarkan hasil uji kecocokan Copula Normal, dapat dikatakan bahwa Copula Normal sangat cocok dalam mencerminkan data bivariat $\left(x_{t}, y_{t}\right)$ untuk Model 3 .

\section{5. Pemilihan Regresi Kuantil Terbaik}

Analisis regresi kuantil dilakukan untuk setiap kombinasi marginal dengan menghitung nilai Mean Square Error (MSE) dan mencari yang terkecil dari 


\section{Pendekatan Generalized Linear Model Pada Regresi Kuantil Copula Normal Untuk Keterhubungan IHSG dan Kurs EUR-IDR \\ d'Cartesian: Jurnal Matematika dan Aplikasi, Vol. 9, No. 2 (September 2020): 97-104}

keempat model. Berikut hasil perhitungan MSE untuk setiap model.

Tabel 6. Nilai MSE dari Regresi Kuantil Copula Normal untuk Setiap Kombonasi Marginal

\begin{tabular}{cccc}
\hline \multirow{2}{*}{ Model } & \multicolumn{2}{c}{ Distribusi } & \multirow{2}{*}{$M S E$} \\
\cline { 2 - 3 } & $X$ & $Y$ & \\
\hline 1 & Normal & Normal & 0.0001025140 \\
\hline 2 & Normal & Laplace & 0.0001028217 \\
\hline 3 & Laplace & Normal & 0.0001022486 \\
\hline 4 & Laplace & Laplace & 0.0001025391 \\
\hline
\end{tabular}

Nilai MSE terkecil dimiliki oleh Model 3, dengan kombinasi distribusi $x_{t} \sim$ Laplace dan $y_{t} \sim$ Normal yaitu sebesar 0.0001022486. Oleh karena itu, dapat dikatakan bahwa regresi kuantil terbaik adalah regresi Model 3 . Kurva regresi kuantil Model 3 disajikan pada Gambar 2 berikut.

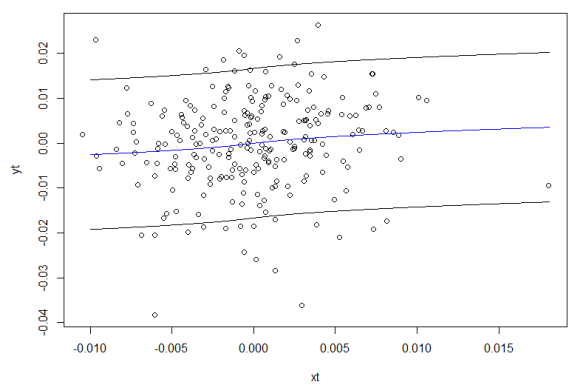

Gambar 2. Kurva Regresi Kuantil Copula Normal dengan $x_{t} \sim$ Laplace dan $y_{t} \sim$ Normal

\section{6. Validasi Parameter Copula}

Validasi parameter copula dilakukan dengan simulasi parametric bootstrap, yaitu dengan mencari $P_{\text {value }}$ dari estimasi parameter copula Normal $\rho$ melalui korelasi Spearman's rho. Selanjutnya, $P_{\text {value }}$ untuk parameter copula Normal $\rho$ hasil simulasi dibandingkan dengan $P_{\text {value }}$ untuk parameter copula Normal $\rho$ dari estimasi dengan pendekatan Generalized Linear Model. Berikut tabel perbandingan kedua $P_{\text {value }}$ tersebut.

Tabel 7. Perbandingan $P_{\text {value }}$

\begin{tabular}{|c|c|c|c|c|}
\hline \multirow{2}{*}{ Model } & \multicolumn{2}{|c|}{ Distribusi } & \multirow{2}{*}{$\begin{array}{c}P_{\text {value }} \\
\text { simulasi }\end{array}$} & \multirow{2}{*}{$\begin{array}{c}P_{\text {value }} \text { dari } \\
\text { estimasi } \\
\text { Least Square }\end{array}$} \\
\hline & $X$ & $Y$ & & \\
\hline 1 & Normal & Normal & 0.104 & 0.0864 \\
\hline 2 & Normal & Laplace & 0.054 & 0.0572 . \\
\hline 3 & Laplace & Normal & 0.076 & 0.0594 \\
\hline 4 & Laplace & Laplace & 0.032 & 0.0375 * \\
\hline
\end{tabular}

Berdasarkan estimasi parameter regresi kuantil Copula Normal dengan Least Square, ditunjukkan bahwa parameter $\rho$ tidak signifikan terhadap o pada interval kepercayaan 90\%, khususnya Model 3 yang terpilih menjadi model terbaik. Validasi parameter Copula Normal $\rho$ membuktikan kebenaran estimasi parameter Copula Normal $\rho$ tidak signifikan terhadap o. Hal ini karena perolehan nilai $P_{\text {value }}$ simulasi yang tidak jauh dari $P_{\text {value }}$ dari estimasi Least Square. Estimasi parameter Copula Normal $\rho$ Model 3 adalah $\rho=$ 0.12437. Oleh karena nilai koefisien korelasi Pearson berada pada interval $[-1,1]$, nilai $\rho=0.12437$ dapat dianggap dekat ke 0 . Hal ini berarti keterhubungan peubah $x_{t}$ dan $y_{t}$ lemah. Berdasarkan grafik regresi kuantil Model 3, ditunjukkan keterhubungan yang tidak linier, karena diperoleh grafik yang melengkung.

\section{KESIMPULAN}

Penelitian ini bertujuan untuk memperoleh parameter dan regresi kuantil Copula Normal yang dapat menjelaskan keterhubungan dua peubah acak pada data bivariat. Tujuan penelitian tersebut telah tercapai. Pertama, estimasi parameter Copula Normal $\rho$ diperoleh dari metode Least Square yang digunakan pada persamaan regresi kuantil Copula Normal yang merupakan Generalized Linear Model yang dikenakan fungsi invers link $G^{-1}(\Phi(\cdot))$. Kurs Beli EUR-IDR dan IHSG secara berurutan berdistribusi Laplace dan Normal dengan parameter keterhubungan copula Normal $\rho=0.12437$. Keterhubungan antara keduanya lemah pada interval kepercayaan 90\% dan nonlinier berdasarkan grafik regresi kuantilnya.

\section{DAFTAR PUSTAKA}

[1] I. Z. Alwi, Pasar Modal: Teori dan Aplikasi, I. Jakarta: Yayasan Pancur Sawah, 2003.

[2] Jamilatuzzahro., R. Herliansyah, and R. E. Caraka, Aplikasi Generalized Linear Model Pada $R$, Yogyakarta: Innosain, 2018.

[3] Hariyanto, L. R. Sasongko, and D. B. Nugroho, "Analisis Kurva Kuantil Bersyarat untuk Data IHSG dan Kurs Beli CNY-IDR,” PROSIDING-M9, 2019.

[4] A. T. P. Najafabadi, M. R. Farid-Rohani, and M. Qazvini, "A GLM-based Method to Estimate A Copula's Parameter(s), J J Iran. Stat. Soc., vol. 12, no. 2, pp. 321-334, 2013.

[5] N. L. Arisandi, D. B. Nugroho, and L. R. Sasongko, "Analisis Prediksi IHSG Berdasarkan Kurs Beli IDR-USD Melalui Regresi Copula," J. Mat. dan Apl. deCartesianN, vol. 7, no. 2, p. 59, 2018.

[6] A. Halim, Analisis Investasi, Jakarta: Salemba Empat, 2005.

[7] L. M. Leemis and J. T. McQueston, "Univariate Distribution Relationships," Am. Stat., vol. 62, no. 1, pp. 45-53, 2008.

[8] B. W. Yap and C. H. Sim, "Comparisons of various types of normality tests," J. Stat. Comput. Simul., vol. 81, no. 12, pp. 2141-2155, 2011.

[9] Y.-K. Tse, Nonlife Actuarial Models Theory, Methods and Evaluation. New York: Cambridge University Press, 2009.

[10] H. C. Thode, Testing for Normality. Stony Brook, New York: Marcel Dekker, Inc., 2002.

[11] T. W. Anderson and D. A. Darling, "Asymptotic 
Theory of Certain 'Goodness of Fit' Criteria Based on Stochastic Processes," Ann. Math. Stat., vol. 23, no. 2, pp. 193-212, 1952.

[12] R. B. Nelsen, An introduction to Copulas (Springer Series in Statistics), 2nd ed. Portland: Springer Science+Business Media, Inc., 2006.

[13] L. R. Sasongko, "Copula untuk Memodelkan Kegagalan Dua Dimensi pada Produk Bergaransi dengan Strategi Penggantian,” Institut Teknologi Bandung, 2014.

[14] C. Meyer, "The Bivariate Normal Copula," Commun. Stat. - Theory Methods, vol. 42, no. 13, pp. 2402-2422, 2013.

[15] C. Bernard and C. Czado, "Conditional Quantiles and Tail Dependence," J. Multivar. Anal., vol. 138, pp. 104-126, 2015.

[16] C. Genest, B. Rémillard, and D. Beaudoin, "Goodness-of-Fit Tests for Copulas: A Review and A Power Study,” Insur. Math. Econ., vol. 44, no. 2, pp. 199-213, 2009.

[17] A. Agresti, Foundations of Linear and Generalized Linear Models. New Jersey: John Wiley \& Sons, Inc, 2015.

\section{Laurentia Nindya Sari Prameswara}

(ayi.laurento03@gmail.com)

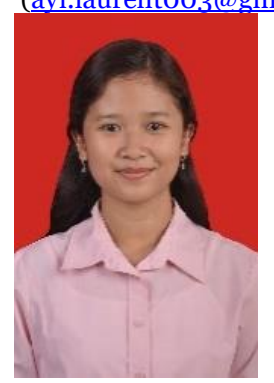

Lahir dan tinggal di Salatiga, Jawa Tengah.

Dia masih menempuh pendidikan tinggi di Program Studi Matematika, Fakultas Sains dan Matematika, Universitas Kristen Satya Wacana (UKSW) Salatiga. Tahun 2020 adalah tahun terakhir ia menempuh studi. Makalah ini merupakan hasil penelitian skripsinya yang dipublikasikan.

Bambang Susanto (bambang.susanto@uksw.edu)

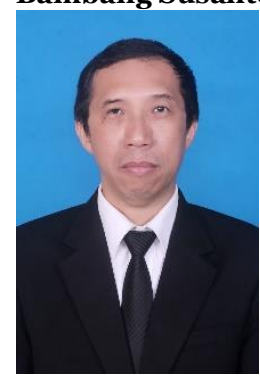

Llahir di Ambarawa, 12 Juli 1963. Lulus sarjana pada tahun 1988 dari Universitas Diponegoro Semarang. Gelar Magister Sain diperolehnya pada tahun 1992 dari Institut Tekonologi Bandung dan Doktor Matematika pada tahun 2005 dari Institut Teknologi Bandung. Sejak tahun 1988, ia bekerja di Universitas Kristen Satya Wacana, Salatiga. Beberapa matakuliah yang diampunya sampai saat ini adalah : Matematika Diskret, Aljabar Linear, Fungsi Kompleks, Geometri Euclid, Statistika Matematika, Komputasi Finansial, Teknik Peramalan dan Analisis Data Multivariat. Bidang penelitian yang diminati adalah time series modeling dan cryptography serta landasan teoritis yang melatarbelakanginya seperti aljabar linear dan matematika diskrit.Berikut dua makalah hasil penelitiannya bersama rekan dosen dan mahasiswa bimbingan: Desain S-Box Fleksibel : Regenerasi Konstanta dan Koefisien Fungsi Linier Berbasis CSPRING Chaos yang dipublikasikan di Jurnal Nasional Teknik Elektro dan Teknik Informatika Vol. 8 No. 1 (2019) dan Modeling of Return Volatility using GARCH(1,1) Model under Tuckey Transformations Jurnal Akutansi dan Keuangan 21(1), Mei 2019, Universitas Petra.

\section{Leopoldus Ricky Sasongko}

(leopoldus.sasongko@uksw.edu)

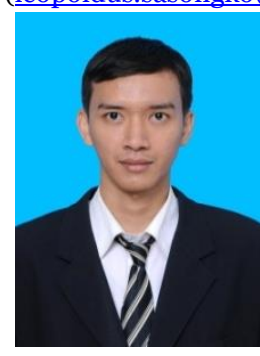

Lahir di Ketapang, Kalimantan Barat, pada tanggal 14 November 1989. Pada tahun 2011, gelar Sarjana Sains (S.Si) diperoleh dari Universitas Kristen Satya Wacana (UKSW) Salatiga. Gelar Magister Sains (M.Si) didapat dari Program Pascasarjana Magister Aktuaria, Institut Teknologi Bandung (ITB), pada tahun 2014

Ia bekerja di UKSW sejak tahun 2011 sebagai Calon Pengajar Akademik (Dosen) di Program Studi Matematika, Fakultas Sains dan Matematika, UKSW. Saat ini, ia menjadi Pengajar Akademik Tetap di UKSW.

Sasongko, M.Si, merupakan salah satu anggota Asosiasi Matematikawan Indonesia, IndoMS. Bidang penelitian yang digeluti adalah Matematika Aktuaria dan Garansi (Warranty). Salah satu makalah hasil penelitian adalah The Estimation of Renewal Functions Using the Mean Value Theorem for Integrals (MeVTI) Method yang terpublikasi di Jurnal Matematika dan Aplikasi deCartesiaN, Universitas Sam Ratulangi (UNSRAT). 